\title{
Study of the mechanical characteristics and chemical degradation of concretes based on machining sludge
}

\author{
Souad Kherbache ${ }^{1}$, Nedjima Bouzidi ${ }^{2}$, Abdelkader Tahakourt ${ }^{1}$ and Karim Moussaceb $^{2}$ \\ ${ }^{1}$ Laboratory of Construction Engineering and Architecture (LGCA) \\ ${ }^{2}$ Laboratory of Materials Technology and Process Engineering (LTMGP) \\ University A/Mira, Faculty of Technology, Department of civil engineering, Bejaia, Algeria
}

\begin{abstract}
The main objective of this work is to study the mechanical characteristics and the chemical degradation of mortars and concretes made obtained by substituting the cement by the machining sludge. Several materials were carried out by substituting the cement with different amount of machining sludge $(5,10$, 15 and 20\%). The obtained materials are compared to those without substitution (ie: 00wt\% of machining sludge). Mechanical and physical properties of the two materials (mortars and concretes) as flexural and compressive strengths were studied. Physical properties as shrinkage, the bloating effect, loss in mass, slump concretes and porosity were evaluated. In addition, chemical degradation is studied for the conservation of these concretes and mortars from machining sludge in different aggressive environment. Moreover, the addition of $5 \mathrm{wt} \%$ of the machining sludge in the mixture of the mortar and the concretes seems to be interesting.
\end{abstract}

\section{Introduction}

The common term "machining sludge" includes several types of industrial waste coming from the mechanical industry: rectification sludge, but also sludge from grinding, mass finishing, etc. [1]. Sludge has long been a wasteful and bulky waste for communities and industrialists [2]. Each year, the mechanical industries produce some 50,000 tons of sludge. To date, $80 \%$ of these sludges are not reused and end up in landfills. Aware of the enormous potential for recovery of this waste, the Carnot Cetim institute has valorised these muds in bricks [3-4]. For this purpose, the valorisation and management of industrial sludge are topical subjects; the valorization of waste (sludge) as alternative raw materials for the manufacture of ceramics has been studied by J.A. Junkes [5].

Due to the increase in sludge treatment costs, industrial sites must design and implement intelligent methods for the treatment, reduction of sludge from processing and recovery of by-products from production. A sustainable waste management system for sludge effluent treatment was a pressing problem. Recycling is always recommended in terms of environmental sustainability; following a waste recovery approach [6]. There are increasing constraints on regulation. The merger constitutes a technologically and economically value-added [7].
Different studies have been carried out on the processes commonly used for the stabilization and treatment of sludge, as well as the new technologies which have been developed in recent years. It should be noted that very good literature reviews on novelties in the field of treatment, use and disposal of sewage sludge are presented annually in the journal «Water Environment Research» [8-13].

Studies have also shown that neglecting the shrinkage phenomenon leads to an overestimation of the internal diffusion coefficient for convective drying of sludge and sawdust / sludge mixtures [14]. Moreover, the presence of high concentrations of toxic metals in sludge constitutes a significant obstacle [15-18]. Conventional sludge treatment processes, such as aerobic or anaerobic stabilization, are inoperative for the removal of toxic metals [19].

Therefore, the treatment of sludge machining is a recurring problem for mechanical companies. On the other hand, the various industries reject equally large amounts of sludge; the latter occupies an increasingly large storage area, which poses the problem of its evacuation. To remedy this, the sludge was recovered from Ain El Kebira's BCR plant in the city of Sétif, Algeria, and was used for the manufacture of concrete and mortar. 
Table 3. Chemical analysis of standard sand.

\section{Materials and methods}

Five (05) specimens of concretes and mortars have been made: a concrete and mortar witnesses without waste addition, and four (04) series of concretes and mortars based on machining sludge in substitution of cement.

The concretes and mortars are prepared in laboratory from the materials listed below:

\subsection{Materials}

\subsubsection{Aggregates}

Locally available natural aggregates, a natural sand with the size of $0 / 3 \mathrm{~mm}$, and two crushed stone aggregates having sizes of $8 / 15 \mathrm{~mm}$ and $15 / 25 \mathrm{~mm}$ are used for the manufacture of concretes. The physical properties and chemical composition of aggregates $0 / 3,8 / 15$ and 15/25 $\mathrm{mm}$ are given in Tables 1 and 2. On the other hand, for the manufacture of mortars, standard sand is used NF EN 196-1, its chemical composition is presented in Table 3.

Table 1. Chemical analysis of sand $0 / 3$.

\begin{tabular}{|c|c|c|c|}
\hline Element & $\mathrm{CaCO}_{3}$ & $\mathrm{Nacl}$ & $\mathrm{SO}_{4}{ }^{2-}$ \\
\hline$(\%)$ & $\mathbf{9 8 . 0 0}$ & $\mathbf{0 1 . 1 7}$ & $\mathbf{0 0 . 0 0}$ \\
\hline
\end{tabular}

Table 2. Physical characteristics of aggregates.

\begin{tabular}{|c|c|c|c|}
\hline Physical characteristics & $\begin{array}{c}\text { Sand } \\
0 / 4\end{array}$ & $\begin{array}{l}\text { Aggregate } \\
8 / 15\end{array}$ & $\begin{array}{c}\text { Aggregat } \\
\text { e } 15 / 25\end{array}$ \\
\hline $\begin{array}{c}\text { Density } \rho_{\mathrm{p}} \text { (NF P 18-554) } \\
\left(\mathrm{g} / \mathrm{cm}^{3}\right)\end{array}$ & 1.44 & 1.40 & 1.28 \\
\hline $\begin{array}{c}\text { Density } \rho_{\mathrm{s}} \text { (NF P 18-555) } \\
\left(\mathrm{g} / \mathrm{cm}^{3}\right)\end{array}$ & 2.54 & 2.56 & 2.73 \\
\hline Porosity & $\mathbf{0 . 4 3}$ & 0.45 & $\mathbf{0 . 5 3}$ \\
\hline $\begin{array}{c}\text { Content of impurities } \\
\text { (NF P 18-598, } \\
\text { NF P 18-591) } \\
(\%)\end{array}$ & $E S=68$ & 0.8 & 0.4 \\
\hline Module of finesse & 2.92 & I & I \\
\hline $\begin{array}{c}\text { MDE (NF P 18-572) } \\
(\%)\end{array}$ & I & 21 & 22 \\
\hline $\begin{array}{c}\text { LA (NF P 18-573) } \\
(\%)\end{array}$ & I & 22 & 25 \\
\hline
\end{tabular}

\begin{tabular}{|c|c|c|c|}
\hline Element & $\mathrm{SiO}_{2}$ & $\mathrm{Al}_{2} \mathrm{O}_{3}$ & $\mathrm{Fe}_{2} \mathrm{O}_{3}$ \\
\hline$(\%)$ & $\mathbf{9 7 . 2 2}$ & nd & nd \\
\hline Element & $\mathrm{CaO}$ & $\mathrm{MgO}$ & $\mathrm{Na}_{2} \mathrm{O}$ \\
\hline$(\%)$ & $\mathbf{0 1 . 3 4}$ & nd & nd \\
\hline
\end{tabular}

\subsubsection{Cement}

An ordinary Portland cement (CPA: CEM I 42.5 according to EN 197-1) is used in the concretes and mortars.

\subsubsection{Machining sludge}

The sludge used in this study (hydroxide sludge), which is an industrial waste from the BCR factory (Ain ElKebira), which has a green color (figure 1). Its mineralogical composition is given in Table 4 .

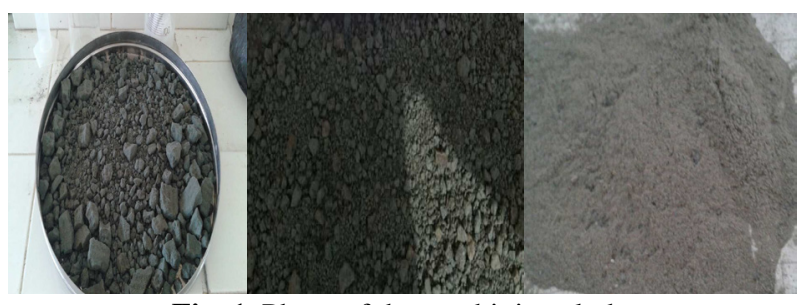

Fig. 1. Photo of the machining sludge.

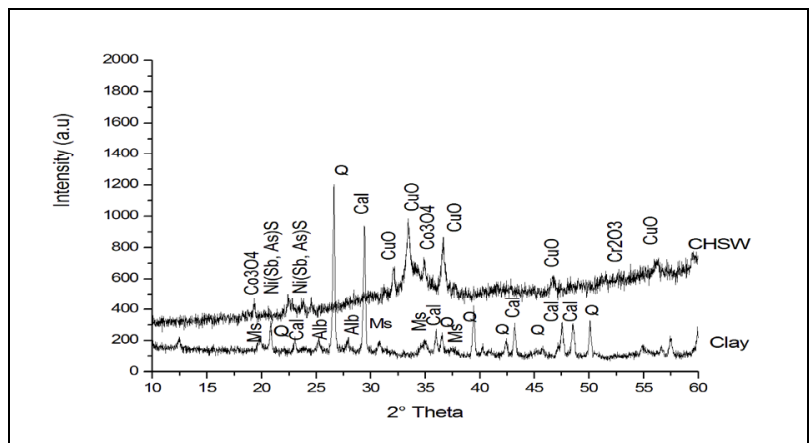

Fig. 2. X-ray diffraction (XRD) of the machining sludge.

Figure 2 presents the XRD analysis of the machining sludge. In the diffractogram to the major peaks of quartz and copper oxide is an indication of the siliceous nature. 
Table 4. Mineralogical composition of the machining sludge.

\begin{tabular}{|c|c|}
\hline Element & $(\mathbf{g} / \mathbf{k g})$ \\
\hline $\mathrm{Ni}$ & 1.66053 \\
\hline $\mathrm{Cd}$ & 0.00867 \\
\hline $\mathrm{Cu}$ & 12.24374 \\
\hline $\mathrm{Zn}$ & 0.36480 \\
\hline $\mathrm{Cr}$ & 20.393 \\
\hline
\end{tabular}

\subsubsection{Water}

The water used is the drinking water of the city of Bejaia, so it does not require any test. It complies with the requirements of the standard (NF EN 1008).

\subsection{Mixture proportions}

\subsubsection{Mortar}

The preparation of formulations of mortar is based on the NF EN 196-1 standard [20]. The formulation is given for five (05) sets of three (03) prismatic test pieces of $(40 * 40 * 160) \mathrm{mm}^{3}$ and its dosage is shown in Table 5 follows:

Table 5. Compositions of fresh mortars.

\begin{tabular}{|c|c|c|c|c|}
\hline Samples & $\begin{array}{c}\text { Hydroxide } \\
\text { sludge } \\
\text { (gr) }\end{array}$ & $\begin{array}{c}\text { Cement } \\
\text { (gr) }\end{array}$ & $\begin{array}{c}\text { Standard } \\
\text { sand } \\
\text { (gr) }\end{array}$ & $\begin{array}{c}\text { Water } \\
\text { (gr) }\end{array}$ \\
\hline M 00\% & $\mathbf{0 0}$ & $\mathbf{4 5 0}$ & $\mathbf{1 3 5 0}$ & $\mathbf{2 2 5}$ \\
\hline M 05\% & $\mathbf{2 2 . 5}$ & $\mathbf{4 2 7 . 5}$ & $\mathbf{1 3 5 0}$ & $\mathbf{2 2 5}$ \\
\hline M 10\% & $\mathbf{4 5}$ & $\mathbf{4 0 5}$ & $\mathbf{1 3 5 0}$ & $\mathbf{2 2 5}$ \\
\hline M 15\% & $\mathbf{6 7 . 5}$ & $\mathbf{3 8 2 . 5}$ & $\mathbf{1 3 5 0}$ & $\mathbf{2 2 5}$ \\
\hline M 20\% & $\mathbf{9 0}$ & $\mathbf{3 6 0}$ & $\mathbf{1 3 5 0}$ & $\mathbf{2 2 5}$ \\
\hline
\end{tabular}

Figure 3 shows how the specimens are stored for the shrinking measurement.

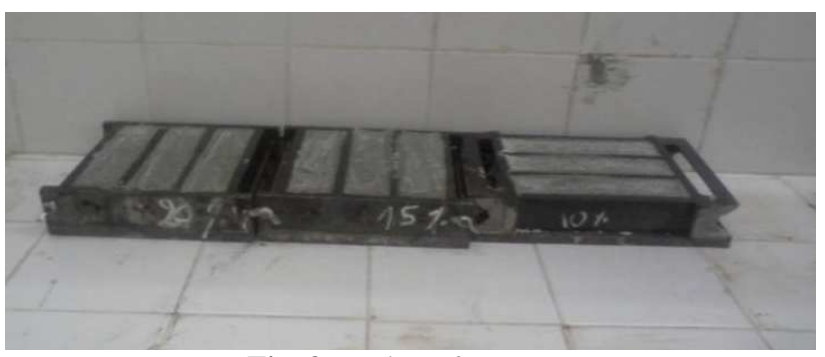

Fig. 3. Drying of mortars.

\subsubsection{Concrete}

The formulation method used in our study is that of DREUX-GORISSE [21], figure 4 gives the detail of the method used. Six (06) concrete test pieces of 16 x $32 \mathrm{~cm}$ were made; the proportions of the various compositions of the concretes are presented in the Table 6.

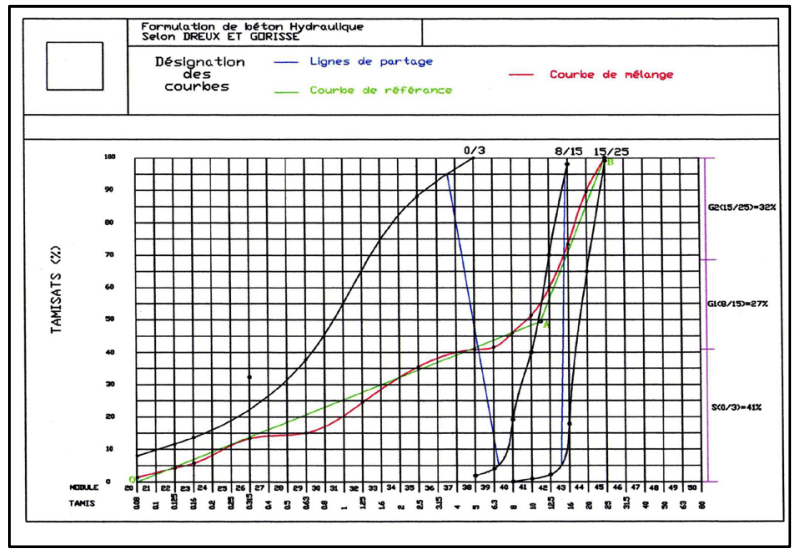

Fig. 4. Curve of mixture of concrete according to Dreux -Gorisse.

Table 6. Compositions of fresh concretes.

\begin{tabular}{|c|c|c|c|c|c|}
\hline Samples & C $00 \%$ & C $05 \%$ & C $10 \%$ & C $15 \%$ & C $20 \%$ \\
\hline $\begin{array}{c}\text { Hydroxi } \\
\text { de } \\
\text { sludge } \\
\text { (kg) }\end{array}$ & - & $\mathbf{0 . 4 4 8}$ & $\mathbf{0 . 8 9 7}$ & $\mathbf{1 . 3 4 6}$ & $\mathbf{1 . 7 9 4}$ \\
\hline $\begin{array}{c}\text { Cement } \\
\text { (kg) }\end{array}$ & $\mathbf{8 . 9 7 4}$ & $\mathbf{8 . 5 2 5}$ & $\mathbf{8 . 0 7 6}$ & $\mathbf{7 . 6 2 7}$ & $\mathbf{7 . 1 7 9}$ \\
\hline $\begin{array}{c}\text { Sand 0/3 } \\
\text { (kg) }\end{array}$ & $\mathbf{1 4 . 9 0 7}$ & $\mathbf{1 4 . 9 0 7}$ & $\mathbf{1 4 . 9 0 7}$ & $\mathbf{1 4 . 9 0 7}$ & $\mathbf{1 7 . 9 0 7}$ \\
\hline $\begin{array}{c}\text { Gravel } \\
8 / 15 \\
\text { (kg) }\end{array}$ & $\mathbf{1 4 . 8 4 2}$ & $\mathbf{1 4 . 8 4 2}$ & $\mathbf{1 4 . 8 4 2}$ & $\mathbf{1 4 . 8 4 2}$ & $\mathbf{1 4 . 8 4 2}$ \\
\hline $\begin{array}{c}\text { Gravel } \\
15 / 25 \\
\text { (kg) }\end{array}$ & $\mathbf{1 5 . 5 9 1}$ & $\mathbf{1 5 . 5 9 1}$ & $\mathbf{1 5 . 5 9 1}$ & $\mathbf{1 5 . 5 9 1}$ & $\mathbf{1 5 . 5 9 1}$ \\
\hline $\begin{array}{c}\text { Water } \\
\text { (kg) }\end{array}$ & $\mathbf{4 . 4 8 1}$ & $\mathbf{4 . 4 8 1}$ & $\mathbf{4 . 4 8 1}$ & $\mathbf{4 . 4 8 1}$ & $\mathbf{4 . 4 8 1}$ \\
\hline
\end{tabular}




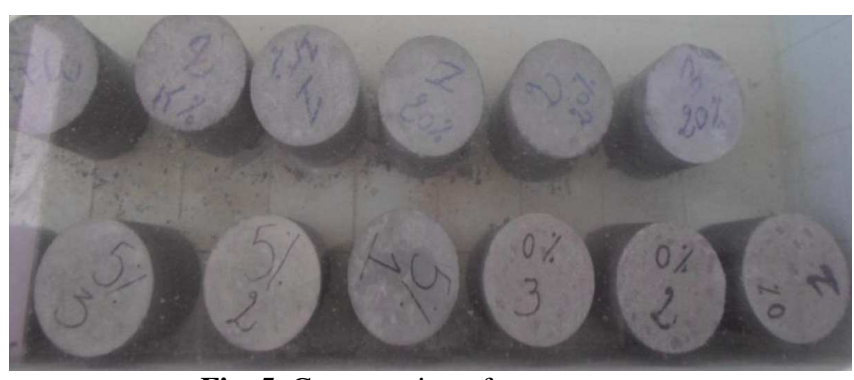

Fig. 5. Conservation of concretes.

\section{Results and discussion}

\subsection{Compressive strength and flexural strength of mortar}

Flexural and compressive strength are presented in figure 6.The value of the flexural strength obtained is the average of three prisms for each series of specimens. The half- prisms of each test-tube obtained break in inflexion will be broken in compression, thus the value of the compressive strength obtained is the average of six half prisms for each series of test-tubes.

From the histogram, it is shown that the compressive strength and traction by inflexion at the age of 28 days decreases progressively with the increasing of the percentage of machining sludge, except for the mortars with 05 and $10 \mathrm{wt} \%$ sludge are good resistances. This diminution is due to the presence of the machining sludge, and to the reduction in the quantity of cement in the mixture. Thus, increasing the $\mathrm{W} / \mathrm{C}$ ratio influences their resistance.

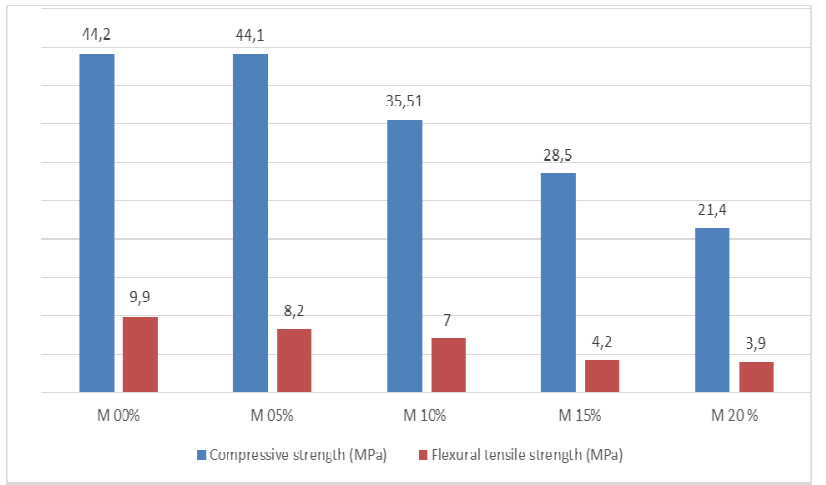

Fig. 6. Effect of machining sludge on the flexural and compressive strength of mortars at 28 days.

\subsection{Measure the shrinkage of mortar specimens}

It is known that the reaction of hydration is accompanied by a reduction of volume, called shrinkage. Water evaporates of a mortar preserved at the free air causing the shrinkage, which is the consequence of the loss of free water, when this water leaves the material, a contraction (shrinkage) occurs automatically. Results introduced above show a behaviour of shrinkage of test specimens at different ages of measure (1 day, 3 days, 7 days, 14 days, 21 days, 28 days, 60 days, 90 days, 120 days, 150 days and 180 days), and in different percentages of machining sludge (00 wt \%, 05 wt $\%, 10$ wt $\%, 15 \mathrm{wt} \%$ and $20 \mathrm{wt} \%$ ), the volume changes occur after hardening. The variation of shrinkage of mortar specimens at different percentages of sludge has almost the same pace (the representative curves have the same evolution) (Figure 7). However, we note that the shrinkage evolves according to time by evaporation of the water imprisoned in the mortars. The shrinking of the mortar witnesses remains the most important, therefore the use of the machining sludge reduces the shrinkage; this fact is due to the reduction in the quantity of cement which induces the lowering of its hydration what translated by consequent in the reduction of shrinking. Our results do not coincide with N. Belas work [22], because in their concrete the $20 \%$ sludge composite gave a larger shrinkage compared to $0 \%, 10 \%$ and $15 \%$.

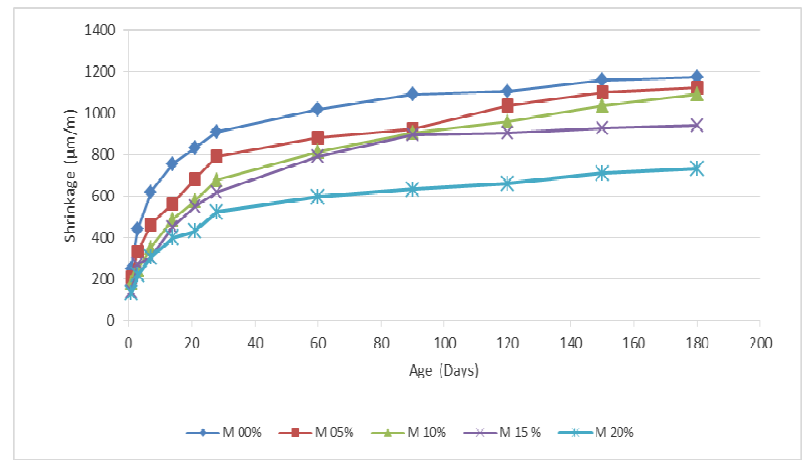

Fig. 7. Effect of machining sludge on the shrinking of the mortars.

\subsection{Measure of swelling on specimens of mortar}

The figure 8 shows that the swelling increases with time and the percentage of machining sludge in substitution of cement, and it starts to be stabilized as from 120 days. This stabilization and increasing the swelling depending on the sludge can be explained by the saturation of the voids created by the addition of sludge. In fact, by substituting the cement by machining sludge, there will be more voids inside the mortar, who promotes the birth of additional pocket of water that induces more swelling.

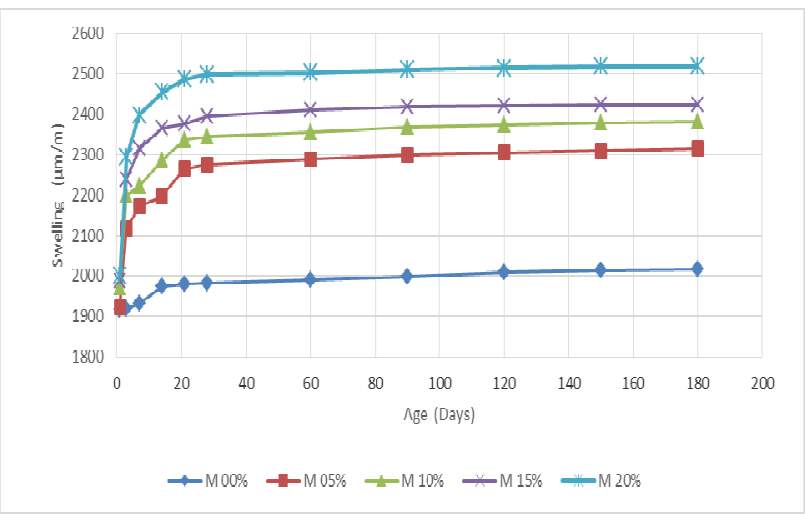

Fig. 8. Effect of machining sludge on the swelling of the mortars. 


\subsection{Evolution of the $\mathrm{pH}$ of solutions of conservation of mortars for swelling}

Accordingly to the figure 9, all mortars have a basic $\mathrm{pH}$, which varies from 8,4 to 11 . This $\mathrm{pH}$ increases according to the time and to the increase of the percentage of sludge in the mortars and stabilizes after 150 days. This alkalinity is due to a progressive and continuous salting out elements of chromium $\left(\mathrm{Cr}^{3+}\right)$ and copper $\left(\mathrm{Cu}^{2+}\right)$, present in the machining sludge, and which form with the water the alkaline bases.

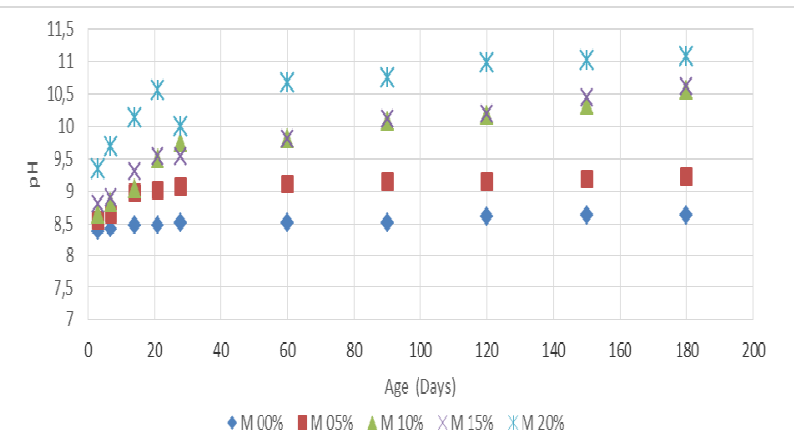

Fig. 9. Evolution of the $\mathrm{pH}$ of conservation solutions.

\subsection{Compressive strength test of concrete}

The compressive strength is an essential characteristic and fundamental parameter of our study. Therefore, measuring at the age of 7 days and at the age of ripening (28 days) was made on different compositions of concrete and the results thus obtained are graphically shown in figure.10. It is observed that the dosage to $00 \mathrm{wt} \%$ of machining sludge (concrete witness) gave a better compressive strength for the proportion in $05 \mathrm{wt} \%$ of sludge and has a slight decrease in strength relative to the concrete witness.

These results were predictable; because the $\mathrm{W} / \mathrm{C}$ ratio was increasing, which is respectively: $0.5,0.52,0.55$, 0,58 and 0.62. Accordingly, the increase of the sludge proportioning in cement substitution, generates a lowering of the compressive strength

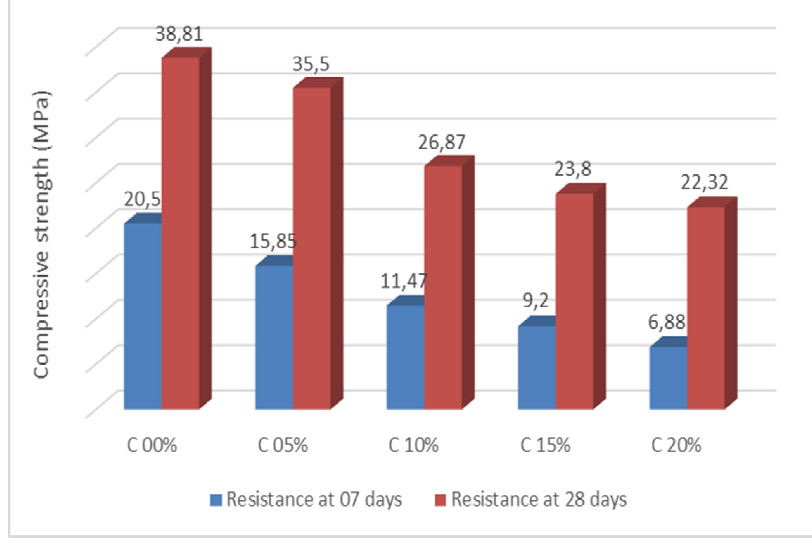

Fig. 10. Effect of machining sludge on the compressive strength of concrete.

\subsection{Chemical analyses of preservative solution}

After the mechanical tests, monoliths from each mortar sample were recovered and stored in demineralised water for 28 days to evaluate the leaching of existing heavy metals into the sludge.

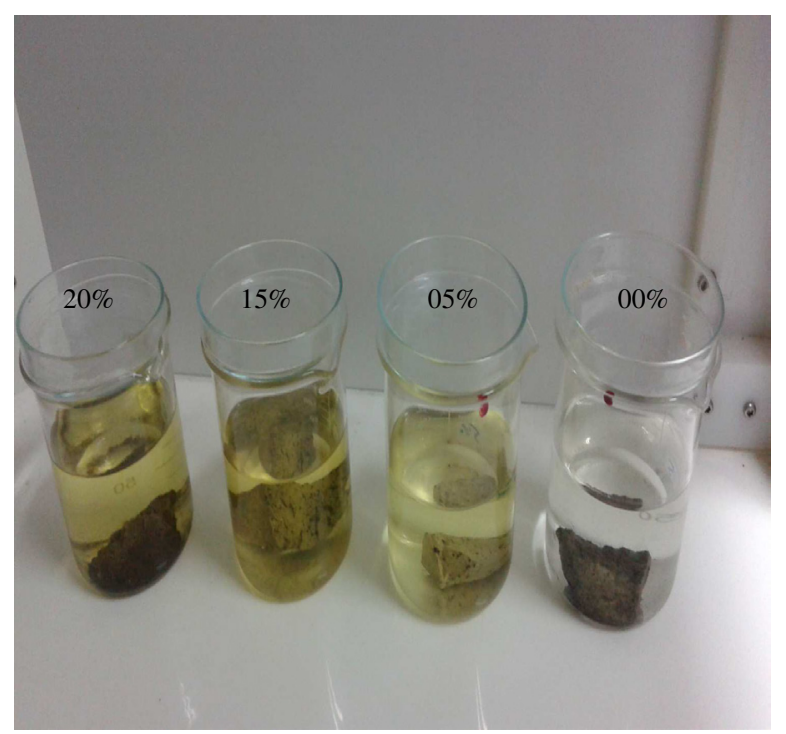

Fig. 11. Study of the leaching of heavy metals of machining sludge on

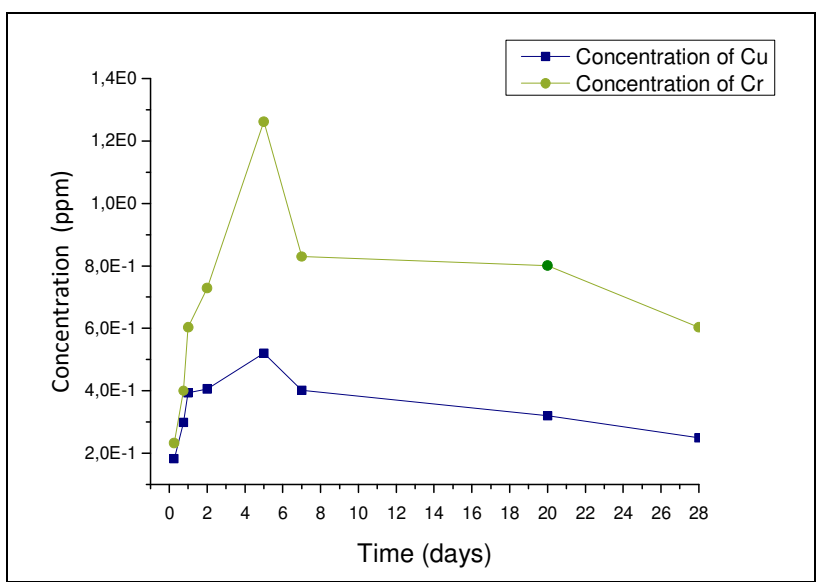

Fig. 12. Evolution of the concentration of chromium and copper as function of time in mortars with $20 \mathrm{wt} \%$ of machining sludge.

Mortar leaching with higher sludge content (20\%) was studied.

The leaching curves of the $\mathrm{Cr}$ and $\mathrm{Cu}$ elements contained in the sludge have almost the same variation as in time (Figure 12).

There is an increase in the concentration of these chemical elements in the preservation solution at a young age; up to five (5) days. This behavior can be related to the leaching of these chemical elements. In addition, a reduction of these elements in the solution is observed up to 8 days; this means that these heavy metals have returned to the matrix of the mortar, and there is a trapping of these elements and then stabilization. The curves clearly show that the concentration of 
chromium metals is higher than that of copper in accordance with the mineralogical composition of the machining sludge.

It can also be said from the results that the leaching rate is low.

\section{Conclusion}

The main interest of this study is to evaluate the influence of the machining sludge in cement substitution on the mechanical and physico-chemical behavior of mortars and concretes. The results showed that the machining sludge can be used as a substitute for 05 wt $\%$ of cement in concrete and mortar, owing to the similar resistance compared to those of mortars and concretes without cement substitution. The use of this machining sludge in cement substitution reduced the shrinkage and the swelling increasing slightly. Therefore, the formulation with $05 \mathrm{wt} \%$ of machining sludge in cement substitution is interesting. The results show good compressive and flexural strengths and acceptable shrinkage and swelling. Moreover it is an economic gain concerning cement. The tests of, all mortars have a basic $\mathrm{pH}$, which varies from 8,4 to 11,2 ; this alkalinity is due to progressive and continuous salting out elements of chromium $\left(\mathrm{Cr}^{3+}\right)$ and copper $\left(\mathrm{Cu}^{2+}\right)$ present in the machining sludge, and which form with the water the alkaline bases. But these quantities of salting out remain always weak.

\section{References}

1. M. Corboz, Le traitement des boues d'usinage, CT.DEC, Thésame, (2017).

2. J. Bertholon, La gestion durable des boues de station d'épuration, Mémoire académique, université de Cergy Pontoise, (2003).

3. J. Ribeyron, L'expertise technique et scientifique de référence, Technique de l'Ingénieur, Le Cetim valorise les boues d'usinage, (2016).

4. Association des instituts Carnot, la recherche pour les entreprises, (2015).

5. J.A. Junkes, F. Raupp-Pereira, V.P. Della, G.G. Cunto and D. Hotza, Valorization of mineral wastes for ceramic industries, The Minerals, Metals \& Materials Society (TMS), (2008).

6. R. Modolo, V.M. Ferreira, M. Rodrigues and I. Coelho, Construction materials as a waste management solution for cellulose sludge, Waste Management (ELSVIER), volume 31, (2011).

7. A. Reynaud, J. Ribeyron, Valorisation des boues d'usinage par fusion Recycling of machining sludge by melting, éditions techniques des industries de la fonderie de Paris, no 192, pp 27-35, 2000.
8. P.T. Bowen, J.M. Entwistle, J.E. Hendrick, J.S. Quilin and U.N. Tyagi, Sludge treatment, utilization, and disposaI. Wat. Environment Res. 60(6), 837-843, (1988).

9. P.T. Bowen, J.E. Hendrick, T.A. Woodward, L.S. Mitchell and M. Lahlou Sludge treatment, utilization, and disposaI. Wat. Environment Res. 61(6), 821-829, (1989).

10. P.T. Bowen, M.K. Jackson and R.A. Corbitt, Sludge treatment, use, and disposaI. Wat. Environment Res. 63(4), 406-414, (1991).

11. P.T. Bowen, M.K. Jackson, R.A. Corbitt and N. Gonce, Sludge treatment, utilization, and disposaI. Wat. Environment Res. 64(4), 378-386, (1992).

12. P.T. Bowen, M.K. Jackson, R.A. Corbitt and N. Gonce, Sludge treatment, utilization, and disposaI. Wat. Environment Res. 65(4), 360-368, (1993).

13. K.A. Groff, L.A. McLaughlin, Sludge management. Wat. Environment Res. 66(4), 368-374, (1994).

14. J. Li , L. Bennamoun , L. Fraikin , T. Salmon , D. Toye, R. Schreinemachers \& A. Léonard, Analysis of the Shrinkage Effect on Mass Transfer During Convective Drying of Sawdust/Sludge Mixtures, Drying Technology, volume 32, (2014).

15. B.J. Alloway et A.P. Jackson, The behavior of heavy metals in sewage sludge-amended soils. Sci. Total Environment 100, 151-176 (1991).

16. A.M. Bruce, et R.D. Davis, Sewage sludge disposal: current and future options. Wat. Sci. Technol. 21, 11131128, (1989).

17. L. Korentajer, A review of the agricultural use of sewage sludge: benefits and potentialhazards. Wat. South Afr,17(3), 189-196, (1991).

18. U.S. Environmental Protection Agency (EPA), Standards for the use and disposal of sewage sludge, 40 CFR Parts 257, 403 and 503, Final Rule. U.S. Environmental Protection Agency, Cincinnati, Ohio, U.S.A, (1993).

19. J.F. Blais et J.L Sasseville, Etat de l'art du traitement et de la disposition ou valorisation des boues d'usines d'épuration municipales, rapport de recherche no 429 , Institut nationale de la recherche scientifique (INRS-Eau), (1996).

20. R. Dupain, R. Lanchon, et J.C. Saint-Arroman, Granulats, sols, ciments et bétons (Caractérisation des matériaux de génie civil par les essais de laboratoir,éditions CASTEILA,(1995).

21. G. Dreux, J. Fiesta, New Guide of concrete and its constituents, (8th edition); Eyrolles Editions (1998).

22. N. Belas, Valorisation des sédiments de dragage dans les bétons, Séminaire Internationale, Innovation \&Valorisation en Génie Civil \& Matériaux de Construction, INVACO2, $\mathrm{N}^{0}$ 1P-173, Rabat, Maroc, 2325 Novembre 2011. 